\title{
AC 2007-1611: THE PHILOSOPHICAL NATURE OF ENGINEERING - A CHARACTERISATION OF ENGINEERING USING THE LANGUAGE AND ACTIVITIES OF PHILOSOPHY
}

William Grimson, Dublin Institute of Technology 


\title{
The Philosophical Nature of Engineering - a characterization of Engineering using the language and activities of Philosophy
}

\begin{abstract}
There is a growing volume of literature concerned with the Philosophy of Engineering or Engineering Science. However to develop a satisfactory overall statement of a 'Philosophy of Engineering' is very challenging, and is perhaps not attainable. To some extent the underlying reason that there cannot be a single coherent engineering philosophy is the highly polyparadigmatic nature of engineering. However some progress is possible by starting with Ludwig Wittgenstein's contention that 'Philosophy is not a theory but an activity'. This paper sets out a perspective on engineering using the available tools and activities of philosophy and thus leading to a philosophical characterization of engineering. Further, the many parallels between philosophy and engineering are observed. It has been pointed out elsewhere that philosophy is like engineering, concerned above all with topics where theory and evidence are not in perfect agreement, and where practical needs force consideration of theories which are known cannot be exactly right. Carl Mitcham has noted that because of the inherently philosophical character of engineering, philosophy may actually function as a means to greater engineering self-understanding. This paper argues that academic programmes could usefully include a module on 'Philosophy in Engineering' in the undergraduate engineering curriculum to provide that enhanced self-understanding, and in turn to relate that understanding to the greater community and contribute therefore to engineers being more accountable to society. The method used in this paper to characterize engineering is based on the direct use of the activities that correspond to the five classical branches of Philosophy - namely Epistemology, Metaphysics, Ethics, Logic, and Aesthetics. The paper also briefly considers Post-modernism and Deconstructionism, the justification being that there are different worldviews and concepts of reality held by society, the very society that engineering aims to serve. This then can act as a guard against the de-contextualising of engineering, a danger that has been highlighted by a number of authors writing about engineering education. The relevance to engineering of each of the branches of philosophy is discussed, and to illustrate the approach a historical design example is presented, where it is acknowledged that it is in design that engineering exhibits its highest intellectual challenge. For the purpose, a simple model of design is presented consisting of the following stages: Requirements, Design, Evaluation, Knowledge Refinement (experience) and Deployment.
\end{abstract}

\section{Introduction}

There is a view widely held by academic staff responsible for engineering education that the appreciation by present day students of 'what is' engineering is poor compared to former times. If this view has validity the causes are likely to be complex but candidate explanations are not hard to find. First, there is a huge pressure on the design of any engineering programme curriculum, often with the inclusion of more science at the expense of practical engineering activities. Second, there has been a steady drift away from general engineering programmes, or programmes with common first or second years, to having specialist ones where exposure to 
general engineering principles is reduced. Third, the pre-entry engineering experience and knowledge of students is probably lower now than in previous times. This is in part explained by the complexity and relative 'un-repairability' of much of today's machines/equipment/devices leading to fewer opportunities for young adults to experiment and learn-by-doing. The conjecture is that the combined impact of the above three has led to a decontexualisation within undergraduate engineering programmes. What are the remedies? A lengthening of programmes to allow for the inclusion of more 'engineering' in the curriculum; the adoption of carefully chosen industrial placement for at least a semester; the inclusion of more problem-based or project-based activities introduced in the early stages of the programme; an increased focus on design reinforced throughout the undergraduate programme and centred on a 'design spine'. All of the above have been adopted in some measure or other with, up to a point, positive results. This paper suggests that an additional combined element - A History of Engineering and Philosophy in Engineering - should be considered for inclusion in undergraduate programmes, possibly as an elective; but the case can be made for making the element mandatory. Why the combination of History and Philosophy? The main argument advanced here is that History and Philosophy, with their well tried methods and tools, can act as 'observers' of Engineering and lead to a useful characterization of that broad discipline. In turn, this would contribute to students having a better self-understanding of what it means to be an engineer. The History component hardly needs much justification and many universities have included history of science and technology courses in their curricula; the objectives being not just that students gain an appreciation of the time-line of influential engineering developments but also to promote an understanding of the social contexts of science and technology. One example of the type of book that might be used is The Fontana History of Technology ${ }^{l}$. And the books by Henry Petroski, Professor of Civil Engineering and Professor of History at Duke University would provide very suitable and interesting material for inclusion in any course dealing with the history of engineering. The remainder of this paper concentrates on the philosophical nature of engineering and attempts to show how the activities of philosophy provide a useful characterization of engineering. Before leaving history it is emphasized that the twin approach of using the 'instruments' of both history and philosophy in tandem to describe engineering is beneficial because of the general and robust applicability of these disciplines and the fact they are so complementary to each other: they each provide a different perspective on engineering and the combined view is thus more complete.

Carl Mitcham has asserted that "because of the inherently philosophical character of engineering, philosophy may actually function as a means to greater engineering self-understanding" and in turn this can lead to an increased understanding of the engineer as a global citizen ${ }^{2}$. This paper aims to show that there are good arguments for considering engineering from a philosophical point of view with specific reference, for example, to Empiricism, Rationalism, Existentialism, Logical Positivist, Post-Modernism, and the Philosophy of Science. Further, as a means of communication, the engineering profession can utilize the tools of philosophy to help enhance the understanding of all citizens regarding how engineers come to their conclusions and solutions.

Finally, in this introduction, it is reasonable to state the view that whilst all human activities are 
amenable to being characterized through the eyes of philosophy, engineering is particularly suitable because of its diverse complexity and nature by which so many views and constraints have to be considered.

\section{Philosophy in Engineering}

Engineering draws its knowledge and inspiration from Science, Mathematics, Architecture, Art and Nature but is neither a super- or sub-set of these disciplines: it has its own distinguishing features. N. Dougherty is quoted as stating that "the ideal engineer is a composite ... he is not a scientist, he is not a mathematician, he is not a sociologist or a writer; but he may use the knowledge and techniques of any or all of these disciplines in solving engineering problems". Engineering can best be compared to Philosophy or at any rate a modern interpretation of what constitutes Philosophy. Adam Morton has stated that "Philosophy is like engineering ... concerned above all with topics where theory and evidence are not in perfect agreement, and where practical needs force us to consider theories which we know cannot be exactly right. We accept these imperfect theories because we need some beliefs to guide us in practical matters. So along with the theories we need rules of thumb and various kinds of model"3. This emphasis on models and rules of thumb, which are invariably imperfect, is necessary if complex systems are to become tractable to any form of analysis and subsequently to allow 'things' to be designed and built. And there is great art in being able to use gainfully those theories that are known to be imperfect and to judge the extent to which rules of thumb may be safely deployed.

So where does Philosophy play its role? A Philosophy of Engineering is an illusive concept, first because of the breadth of engineering with its super abundance of paradigms, but also because philosophy itself is not easily defined. So how does one proceed? An engineer might attempt the sound practice of extrapolating from firmer ground and derive a definition of Philosophy of Engineering from, say, a Philosophy of Science. Yet this carries no guarantee of success. Consider within a Philosophy of Science, for example, the falsifiability principle as viewed against failure in engineering. Falsifiability is held to be an important test in science but has no equivalent role in engineering. On the other hand the role that failure or partial failure plays in the development of engineering design in fact is fundamental, as pointed out by Henry Petroski in much of his writing and especially in his book To Engineer is Human: The Role of Failure in Successful Design ${ }^{4}$. In short, generalizing a Philosophy of Science to encompass Engineering is, at best, problematic. Instead of attempting to develop a Philosophy of Engineering an alternative is to go back to the basics of philosophy and develop a set of attributes, characteristics or even principles that collectively state something specific to or about engineering. Ludwig Wittgenstein considered that "Philosophy is not a theory but an activity", so one conclusion might be that the most that one can produce from philosophy is to use its activities and produce a set of observations which taken together characterize engineering. One direct way of starting this observation process then is to work within the main branches of classical philosophy and to explore what they can 'say' about engineering. What are the main branches? The following section presents an overview of the main branches of philosophy and also gives the collective views of a group of professional engineers as to the relevancy of these branches to engineering. 


\section{The tools of Philosophy and their relevance to Engineering}

Historically the five main branches are generally agreed to be Epistemology, Metaphysics, Ethics, Logic, and Aesthetics. The contention is that by careful reflection on what constitutes engineering from the perspective of each of the above five branches, something definitive emerges about 'engineering': in effect the branches are the 'microscopes/telescopes' that are used to examine and observe the subject.

Table 1 summarizes the five branches of philosophy, and provides a simple description of each branch, and gives some examples of the categories within each division. It is admitted that the 'question' that each branch attempts to address has shifted over the centuries but the definitions given in the Table are broad enough for the purpose of this paper.

Table 1. The five main branches of Philosophy

\begin{tabular}{|c|c|c|c|}
\hline & Description & $\begin{array}{l}\text { Some main } \\
\text { questions }\end{array}$ & $\begin{array}{l}\text { Categories } \\
\text { (examples) }\end{array}$ \\
\hline Epistemology & $\begin{array}{l}\text { Process by } \\
\text { which } \\
\text { knowledge is } \\
\text { gained }\end{array}$ & $\begin{array}{l}\text { What is knowable? } \\
\text { How is it } \\
\text { acquired? } \\
\text { Is it valid? }\end{array}$ & $\begin{array}{l}\text { Rationalism and } \\
\text { Empiricism. } \\
\text { Logical-positivism } \\
\text { etc. }\end{array}$ \\
\hline Metaphysics & $\begin{array}{l}\text { Study of reality } \\
\text { that is beyond } \\
\text { the physical }\end{array}$ & $\begin{array}{l}\text { Existence of God, } \\
\text { the soul, and the } \\
\text { afterlife. } \\
\text { What is existence? }\end{array}$ & $\begin{array}{l}\text { Investigation into } \\
\text { the nature of } \\
\text { reality. } \\
\text { Uncovering what } \\
\text { is ultimately real. }\end{array}$ \\
\hline Ethics & $\begin{array}{l}\text { Study of moral } \\
\text { value, right and } \\
\text { wrong }\end{array}$ & $\begin{array}{l}\text { Placing value to } \\
\text { personal actions, } \\
\text { decisions, and } \\
\text { relations }\end{array}$ & $\begin{array}{l}\text { Moral theory. } \\
\text { Virtue ethics. } \\
\text { Religion and } \\
\text { ethics. Applied } \\
\text { ethics } \\
\end{array}$ \\
\hline Logic & $\begin{array}{l}\text { Study of right } \\
\text { reasoning }\end{array}$ & $\begin{array}{l}\text { Tool used to study } \\
\text { other philosophical } \\
\text { categories }\end{array}$ & $\begin{array}{l}\text { Propositional logic } \\
\text { and predicate } \\
\text { calculus. Quantum } \\
\text { logic. Temporal } \\
\text { logic }\end{array}$ \\
\hline Aesthetics & $\begin{array}{l}\text { Study of art and } \\
\text { beauty }\end{array}$ & $\begin{array}{l}\text { What is the } \\
\text { relationship } \\
\text { between beauty } \\
\text { and art? } \\
\text { Are there objective } \\
\text { standards? } \\
\text { Is beauty in the eye } \\
\text { of the beholder? } \\
\text { Form versus } \\
\text { function. }\end{array}$ & $\begin{array}{l}\text { Aesthetics in the } \\
\text { arts. Aesthetics in } \\
\text { the sciences. } \\
\text { Aesthetics in } \\
\text { engineering } \\
\text { (design). }\end{array}$ \\
\hline
\end{tabular}

As an exercise, 30 professional engineers (Licensed Engineers or Chartered Engineers) were asked using a questionnaire to consider the definitions of the five branches of philosophy and to give their opinion as to the relevance of each branch to engineering. In addition the contributors were asked to provide a simple ranking for the 'relevancy' (High, Medium, Low). It is stressed here that the exercise was a limited one and included engineers in Ireland only and those with at least ten years of experience. A more formal exercise is planned which will include engineers at various stages of development and involve a number of countries in Europe and North America. For the present, the results obtained from the exercise give a strong indication that the branches 
of philosophy are indeed considered relevant to engineering and the overall conclusions are summarized as follows:

1. Ethics: The highest ranking (High) was given by all respondents to Ethics. This reflects, it is believed, modern concerns with a whole range of issues, for example: global equity in relation to the provision of healthcare, in which engineering inputs are crucial (consider the provision of clean water and good sanitation); the nuclear energy debate; pollution; environmental impact; global warming, just to mention a few obvious ones. The issue of 'whistleblowing' was also mentioned.

2. Metaphysics: this branch was given the lowest ranking (Low) by all but two respondents. This is not surprising; after all many famous Philosophers gave metaphysics short shrift. But a more modern interpretation of what constitutes metaphysics might well have elicited a higher ranking, and this will be addressed in the new exercise.

3. Logic: this branch was clearly valued as an activity by all respondents, and responses indicated the relevance of studying different systems of logic (not just mathematical logic as might have been expected). Respondents noted that engineering management, for example often had the characteristics of applied logic. Others noted that in digital electronics that specialized logic was involved. The overall ranking was Medium.

4. Aesthetics: here the response was somewhat muted. Slightly less than half the respondents awarded a ranking of Medium and the balance a ranking of High. Without attempting to infer too high a level of significance, those from a Civil Engineering or Structural Engineering background were more likely to assign a High relevance ranking than those from an Electronic or Computer Engineering background. The reason is perhaps due to the more public visibility dimension to the works of the former. It might be asserted that a sister discipline such as Architecture would highly rank Aesthetics; and Civil and Structural Engineering are their first cousins! The median ranking was High.

5. Epistemology: this branch of Philosophy was given the second highest (after Ethics) degree of relevancy to Engineering (High). Also, the respondents on a 'follow-up' dialogue were generally well acquainted with many of the sub-branches of the activity. Not surprisingly Rationalism and Empiricism were well understood!

Conclusion: as stated above the exercise was in many respects limited, however a reasonable inference can be drawn that the majority of engineers consider that at least four of the branches of philosophy do have a direct relevance to engineering.

Do Post-modernism and its some-time associate Deconstructionism have something relevant to say about engineering and to engineers? When someone as eminent as Noam Chomsky finds the language, definitions and hence concepts of post-modernism difficult to fathom, it is not unreasonable to feel somewhat suspicious or even dismissive of the 'school'. Post-modernism is often used in the context of movements in the arts, economic and social conditions and seldom if ever with respect to engineering. But it is precisely because of the social and economic aspects of post-modernism that engineers need to be made aware of the 'message' and to understand its relevancy. A definition offers post-modernism as "a worldview that emphasizes the existence of different worldviews and concepts of reality, rather than one 'correct or true' one. Whereas modernism emphasized a trust in the empirical scientific method, and a distrust and lack of faith 
in ideologies and religious beliefs that could not be tested using scientific methods; postmodernism emphasizes that a particular reality is a social construction by a particular group, community, or class of persons" $"$. This definition would be identified with, probably, by any engineer in charge of virtually any large project such as, for example, the building of a large hydro-scheme in a hitherto untouched and rural valley or building a nuclear power station close to a large conurbation. In these cases the various classes of persons involved most certainly have different realities and society has progressively provided more legislation for the articulation of those realities. Engineers have to and indeed do deal with these realities, sometimes much to their frustration and that of the sponsor.

A few words about deconstructionism which has been controversial, to say the least, within academic communities. The underlying concepts are that 'truth' and 'rationality' are social constructs that depend on the 'where' and the 'when'. This does not seem to be in any way radical - provided a reasonable interpretation is allowed. It would be hard to convince an engineer or scientist that ' $1+2$ ' is anything other than ' 3 '. However engineers would generally have no difficulty in acknowledging that some 'truths' are really only opinions. What has been radical and certainly contentious is the application of deconstructuralist tools to a range of topics, to such an extent that the work of Foucault, Jacques Derrida and others, seem like an onslaught on intellectual tradition. If Art and Literature have been the main battlefields, science has not exactly escaped. Engineering to a considerable degree has not been a target, which is odd considering its almost overwhelming impact on the world in which we live and bearing in mind that it is complex and involves societal considerations amongst its many concerns. This is not simple territory, however, for at the root of the problem there is again the problem of definition: for example we might say that at one level deconstructionism is essentially nihilistic in nature and promotes an attack, in particular, on Western scientific and ethical values. But a more positive interpretation would be along the lines of taking deconstructionism to be a way or method of uncovering the questions and assumptions behind a text or tradition.

There are different flavours of post-modernism and deconstructionism and there are corresponding groups of evangelists. Notwithstanding the lack of a clear set of definitions and approaches, there is a framework to work within, and engineers do need to engage with these two philosophies because they are saying something about our society and its values, and hence there is a need to discern what is relevant to the practice of their profession.

A longer paper could explore the specific relevance of Ethics and Aesthetics to engineering. Suffice for the purpose of this paper just to mention as an example the Online Ethics for Engineering and Science Centre at Case Western Reserve University. The Case website states that its "mission is to provide engineers, scientists, and science and engineering students with resources for understanding and addressing ethically significant problems that arise in their work, and to serve those who are promoting learning and advancing the understanding of responsible research and practice in science and engineering"7. Regarding Aesthetics, one might refer to the straightforward and very readable text by Alastair Macdonald, or to the deeper, "Engineering Aesthetics and Ergo-Aesthetics: Theoretical and Methodological Foundations" 8,9 . These and others not included here certainly support the notion that these branches of philosophy are considered to have strong relevance to engineering. 
As the essence of epistemology is the nature, source, and scope of knowledge, a few special words about this branch is justified in the context of 'looking' at engineering.

\section{Epistemology}

It is important that engineers understand the nature and provenance of knowledge, where by provenance it is meant both the authority associated with at least an adequate description of the knowledge together with some workable statement as to the limitations of that knowledge. How knowledge is 'discovered', recorded, communicated to others, used, and subsequently revised is the essence of the matter. To some extent science is more concerned with the 'discovery' phase whereas for engineering the nature of how the knowledge came to be known is of much less importance than the ability to communicate and use the knowledge gainfully.

Table 2 lists some of the principal theories of epistemology together with short definitions. In addition some comments are presented as to the role or applicability of each category of knowledge within engineering. The definitions are loosely based on a number of sources including the Oxford English Dictionary. It may well be worth the effort at a later date to explore in depth the linkages between the various epistemological theories and how engineers use them, whether implicitly or explicitly, but that exercise cannot be carried out here. The goal here is simply to demonstrate that the exercise is relevant and that it helps gain an understanding of where engineers obtain their knowledge or more specifically the nature of the knowledge. Some inferences can be drawn as follows:

1. Engineering is not just Applied Science but Science is important. So the Philosophy of Science is relevant ...up to a point.

2. Mathematics for example, which is not a Science, is very important to Engineering and hence Rationalism is relevant.

3. Observation, even when no scientific theory is being tested is of importance to Engineering and Empiricism is fundamental to how Engineers work.

4. The Human as an individual or as a set of people is of course of paramount importance. Engineering exists primarily for the purpose of providing mankind with objects and services intended for their benefit. Both Existentialism and Transcendental idealism therefore have something important to 'say' to the Engineering profession, even if these theories are not in everyday use amongst its members.

It is in the engineering design process more than anywhere else that all of the above has its greatest impact. Design is often a hard and intellectually demanding exercise in engineering. The act of designing can be thought of as a balancing act. The choice and marshalling of the relevant domain knowledge, the understanding of the constraints, the selection of design approaches, deciding which technologies to use, consideration of alternatives ... all of this and more is typical of 'designing'. To bring this all together, the rational and sometimes the irrational, the scientific and the mere opinion, is the art of the engineer. The key point is that engineering uses knowledge in all its various forms to best advantage with no special allegiance given to any one epistemological theory. This may seem a description of a type of mongrel activity, but engineering needs to have this characteristic if any progress is to be made. 
Table 2: Theories of Epistemology and relevance to Engineering

\begin{tabular}{|c|c|c|}
\hline $\begin{array}{l}\text { Epistemology } \\
\text { Theory }\end{array}$ & Definition & Engineering dimension \\
\hline Empiricism & $\begin{array}{l}\text { Based on experience, a result of observation. The } \\
\text { doctrine which regards experience as the only source of } \\
\text { knowledge. }\end{array}$ & $\begin{array}{l}\text { Very much to the fore in } \\
\text { engineering disciplines. }\end{array}$ \\
\hline Rationalism & $\begin{array}{l}\text { Ideas not derived from our experience or observation. } \\
\text { Based on pure thought. A theory (opposed to } \\
\text { empiricism or sensationalism) which regards reason, } \\
\text { rather than sense, as the foundation of certainty in } \\
\text { knowledge. }\end{array}$ & $\begin{array}{l}\text { Clearly some knowledge is } \\
\text { Rationalist in nature but for the } \\
\text { engineer subsequent justification } \\
\text { from experience is valued. } \\
\text { Mathematics is a good example, } \\
\text { and is of direct relevance to } \\
\text { Engineers. }\end{array}$ \\
\hline Positivism & $\begin{array}{l}\text { The only authentic knowledge is scientific knowledge. } \\
\text { Or more generally, any of various philosophical } \\
\text { systems or views based on an empiricist understanding } \\
\text { of science, particularly those associated with the belief } \\
\text { that every cognitively meaningful proposition can be } \\
\text { scientifically verified or falsified. }\end{array}$ & $\begin{array}{l}\text { Engineering could never have } \\
\text { developed based on such a narrow } \\
\text { definition of knowledge. Planes } \\
\text { flew before Engineers had } \\
\text { available sound aerodynamic } \\
\text { scientific 'knowledge'. }\end{array}$ \\
\hline Logical positivism & $\begin{array}{l}\text { Also called logical empiricism, rational empiricism, } \\
\text { and includes the Verifiable principle; its alternative } \\
\text { (anti-logical positivism) is Popper's falsifiability } \\
\text { principle. Logical positivism, the name given to the } \\
\text { theories and doctrines of philosophers active in Vienna } \\
\text { in the early 1930s (the Vienna Circle), which were } \\
\text { aimed at evolving in the language of philosophy formal } \\
\text { methods for the verification of empirical questions } \\
\text { similar to those of the mathematical sciences, and } \\
\text { which therefore eliminated metaphysical and other } \\
\text { more speculative questions as being logically ill- } \\
\text { founded }\end{array}$ & $\begin{array}{l}\text { Engineers can work satisfactorily } \\
\text { without considering this theory. }\end{array}$ \\
\hline Idealism & $\begin{array}{l}\text { What we perceive as the external world is in some way } \\
\text { an artifice of the mind. }\end{array}$ & $\begin{array}{l}\text { Not held to be relevant by most } \\
\text { engineers it is conjectured! }\end{array}$ \\
\hline Existentialism & $\begin{array}{l}\text { Existentialism considers that action, freedom and } \\
\text { decision as fundamental to human existence. } \\
\text { Underlying themes and characteristics, such as anxiety, } \\
\text { dread, freedom. To a large extent Existentialism is at } \\
\text { odds with the Western rationalist principles: it takes } \\
\text { into account human beings' actions and interpretations } \\
\text { however irrational they may seem. }\end{array}$ & $\begin{array}{l}\text { Increasingly important } \\
\text { perspective for Engineering to } \\
\text { take into account the Human } \\
\text { dimension to a greater extent than } \\
\text { at present. }\end{array}$ \\
\hline $\begin{array}{l}\text { Philosophy of } \\
\text { Science }\end{array}$ & $\begin{array}{l}\text { Hypothesis, Prediction, followed by Experimentation } \\
\text { and supporting or denying the hypothesis. }\end{array}$ & $\begin{array}{l}\text { Many engineers see this as a } \\
\text { mixture of rationalism and } \\
\text { empiricism. Engineering both } \\
\text { contributes to knowledge thus } \\
\text { gained and inherits knowledge } \\
\text { directly from the work of } \\
\text { scientists. }\end{array}$ \\
\hline $\begin{array}{l}\text { Transcendental } \\
\text { idealism }\end{array}$ & $\begin{array}{l}\text { Unlike Idealism does not claim that the objects of our } \\
\text { experiences would be in any sense only within our } \\
\text { minds. Perception is influenced by the categories and } \\
\text { the forms of sensation, space, and time, which we use } \\
\text { to understand the object. }\end{array}$ & $\begin{array}{l}\text { This is relevant, surely, to what is } \\
\text { happening at design stages where } \\
\text { the context of society and end- } \\
\text { users must be considered together } \\
\text { with many other constraints. }\end{array}$ \\
\hline
\end{tabular}




\section{A Model of Engineering}

Engineering practice is built on the 'learning' that comes from applying existing knowledge together with suitable design paradigms or heuristics to produce 'outcomes' which in time contribute to 'experience' leading in turn to knowledge refinement. This could be called evidence-based engineering. The historical approach taken by engineers to arrive at an engineering solution to a problem, however large or small, has been to develop a model of the required system. The solution, of course, cannot be divorced from the 'purpose' and general objectives of the enterprise. To be equipped with the required skill set to solve the problem, or design and implement the system, a knowledge base is required. Having the required body of knowledge, the engineer is equipped to implement or develop the design tools necessary to achieve the required outcomes for the project in hand. Through time, experience is gained enabling knowledge to be refined which will further enhance system design capabilities.

The engineering model described in Figure 1 depicts where activities which are philosophical in nature are most to the fore ${ }^{10}$. Epistemology, indeed Logic, Ethics and Aesthetics are fundamental to the creative design processes essential to good engineering practice. Knowledge in engineering, science and technology has grown through the activities of engineers, scientists and technologists, not only in the increasingly shared global experience of recent decades, but over hundreds and indeed in some instances thousands of years. Logic is a fundamental tenet of engineering too, not only in orchestrating a set of complex activities but also within individual activities such as, for example, in the use of mathematics or in aspects of digital electronics. Good ethical practice in the engineering and scientific professions is of increasing importance to every aspect of modern day living.

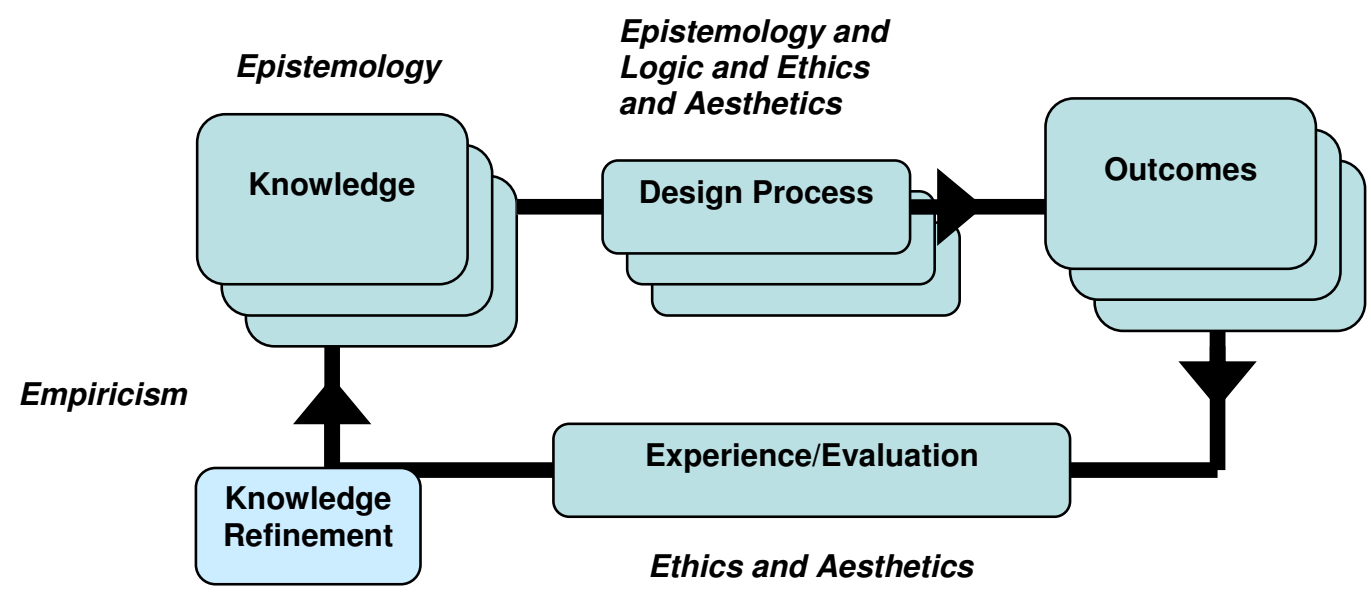

Figure 1. A Model of Engineering: Links to Philosophy

Ethical considerations are now much to the fore and most engineering institutions have a Code of Ethics. Initially these documents were very limited in scope but the flavour now is to take on board more complex issues and provide guidelines and statements of best practice. The Space Shuttle Challenger disaster has caused the engineering profession to think more deeply about ethics and ethical practice. Coupled with other 'disasters' in the professional world, for example the circumstances leading to the collapse of the Enron Corporation, it is abundantly clear that the 
engineering profession amongst other professions has an obligation to ensure that its members are educated in a way that helps ensure that they practice in an ethical way or at least in an ethics aware-manner.

Just as for ethical considerations, aesthetics is not an optional addendum to the engineering design portfolio. As with architectural design, aesthetic application and appropriate use of sustainable materials in the design process are both essential and fundamental to the teaching and practice of engineering. Aesthetical considerations relate to the perceived worth and value of things and are above and beyond the purely monetary aspects. The following section outlines an engineering design example that illustrates how philosophical perspectives can be applied to various aspects of the enterprise.

\section{The Crystal Palace}

The Great Exhibition of 1851 in London was designed to showcase the industrial and economic superiority of Great Britain. But in some respects the most interesting feature of the Exhibition was the building in which it was housed - the Crystal Palace. This building was a triumph of structural engineering, architecture, and use of materials, and its influences on later designs were manifold. It is a remarkable story of how Joseph Paxton was chosen to design the building since he was neither an engineer or architect. The 245 plans submitted for the main Exhibition Hall in Hyde Park were each found wanting. Paxton learned about these difficulties and in a very short period produced a plan which was accepted - a brilliant decision by the building committee as it turned out. Amongst the many remarkable features of the building were: it was relatively cheap, it was simple to erect and remove, it was modular being based on a prefabricated design, and the use of glass was its key feature, hence the name Crystal Palace. There is not a lot of literature available on Paxton's Crystal Palace, though there are a few websites in existence that give some information. An account of the story is given in chapter 12 of To Engineer is Human: the role of failure in successful design ${ }^{4}$ and also in Invention by Design: how Engineers get from Thought to Thing ${ }^{11}$.

What follows is a tabulation of some of the main aspects of the design and construction and its influences together with reference to philosophical concepts, see Table 3 on the next page. Of course the treatment here it is admitted is shallow but it serves to illustrate the point, it is hoped, that in engineering with its broad scope and sets of challenging tasks the categorization of activities can be expressed in philosophical terms and thus confirm the opinion of Andrew Morton stated earlier.

Referring back to Figure 1, Paxton and those who assisted him understood their brief or challenge and utilized their knowledge bank (Epistemology) to arrive at an innovative design. They had experiential knowledge available through Paxton's design and construction of large greenhouses, they had expert knowledge available on cast and wrought iron, but putting this to good use demanded a lot more. To provide the amount of space required and to do so with a building that the public and exhibitors would like and be sympathetic to the environment and landscape took great ingenuity. First Logic had to be brought to bear so that the design could be realized - the production and management of the project within a very tight time constraint was itself a remarkable feature of the Crystal Palace enterprise. 
Table 3: Some characteristics of the Crystal Palace design with reference to philosophical aspects.

\begin{tabular}{|c|c|c|}
\hline Aspect of the Crystal Palace & $\begin{array}{l}\text { Feature of Design, Construction, } \\
\text { Influence }\end{array}$ & Philosophical viewpoint \\
\hline Background of Joseph Paxton & $\begin{array}{l}\text { Gardener by background. } \\
\text { Developed skill in design and } \\
\text { construction of large greenhouses } \\
\text { and conservatories }\end{array}$ & $\begin{array}{l}\text { Epistemology: Experiential } \\
\text { knowledge. Empiricism. } \\
\text { Aesthetics: Clients required that } \\
\text { the 'look' of the conservatories } \\
\text { reflected their artistic taste and be } \\
\text { sympathetic to surrounding } \\
\text { houses and gardens. }\end{array}$ \\
\hline $\begin{array}{l}\text { Location in Hyde Park } \\
\text { contained tall elms }\end{array}$ & $\begin{array}{l}\text { Transept designed to enclose the } \\
\text { trees }\end{array}$ & $\begin{array}{l}\text { Aesthetics, but also post-modern: } \\
\text { Taking account of different } \\
\text { world views and values!! }\end{array}$ \\
\hline Modular design & $\begin{array}{l}\text { Paxton used his own experiences } \\
\text { but also took advice from Peter } \\
\text { Barlow a railroad engineer who } \\
\text { sized the columns and girders } \\
\text { supporting the glass walls }\end{array}$ & $\begin{array}{l}\text { Logic: Paxton conceived of an } \\
\text { approach that used pre-fabricated } \\
\text { components of a regular size that } \\
\text { allowed for a dry-site and rapid } \\
\text { means of construction }\end{array}$ \\
\hline \multirow[t]{2}{*}{ Innovation } & $\begin{array}{l}\text { Supporting columns also acted as } \\
\text { drainpipes } \\
\text { Depth of girders and trusses }\end{array}$ & $\begin{array}{l}\text { Aesthetics: Form and function. } \\
\text { Exercise in Logic. } \\
\text { Aesthetics: Visually graceful but } \\
\text { also served to provide the } \\
\text { necessary structural stiffness }\end{array}$ \\
\hline & $\begin{array}{l}\text { Novel Construction techniques } \\
\text { were employed to make the } \\
\text { operation more efficient }\end{array}$ & $\begin{array}{l}\text { Logic and Empiricism: Pre- } \\
\text { fabricated and standardized units } \\
\text { made the construction easier } \\
\text { became commonplace }\end{array}$ \\
\hline Galleries & $\begin{array}{l}\text { Galleries provided to give } \\
\text { additional exhibition space. }\end{array}$ & $\begin{array}{l}\text { Ethics: Concerns for safety were } \\
\text { well addressed. }\end{array}$ \\
\hline Construction and Maintenance & $\begin{array}{l}\text { Floors designed to allow dust and } \\
\text { small bit of paper to drop between } \\
\text { and below boards and subsequently } \\
\text { be collected to avoid a fire hazard }\end{array}$ & $\begin{array}{l}\text { Ethics: Safety } \\
\text { Aesthetics: Tidy, Out of sight! } \\
\text { Exercise in Logic. }\end{array}$ \\
\hline Curtain wall & $\begin{array}{l}\text { Walls hung 'like curtains' from } \\
\text { discrete fastenings and don't } \\
\text { function as load bearing part of the } \\
\text { structure. Many modern designs } \\
\text { use this concept }\end{array}$ & $\begin{array}{l}\text { Rationalism: Design needed this } \\
\text { solution, which was novel. } \\
\text { Empiricism: Found to work well } \\
\text { in practice and adopted by many } \\
\text { other designers. }\end{array}$ \\
\hline Testing of girders/columns & $\begin{array}{l}\text { Reliability of structural components } \\
\text { was such that every cast component } \\
\text { was tested before delivery to site. } \\
\text { Knew that wrought iron was more } \\
\text { dependable }\end{array}$ & $\begin{array}{l}\text { Ethics and Empiricism: Safety } \\
\text { conscious but also demonstration } \\
\text { of an empirical approach }\end{array}$ \\
\hline Influence & $\begin{array}{l}\text { Large spaces, atriums used by } \\
\text { many designers of high profile flag- } \\
\text { ship corporate buildings }\end{array}$ & $\begin{array}{l}\text { Aesthetics and Knowledge and } \\
\text { Empiricism: What works, looks } \\
\text { well, and is buildable and can be } \\
\text { executed to a high standard }\end{array}$ \\
\hline
\end{tabular}


The Empiricism involved is clear enough, but the dimension of Aesthetics is also strongly in evidence, hence the magical mix of form and function that was often ascribed to the building. The ability to have a design that was affordable, avoiding not over-taxing the erectors, took safety into account in many different ways, be capable of re-use, counts as being Ethically satisfactory. There was certainly a demonstration of Logic applied to, not just in the design, but more so in the method of construction. In terms of influencing later generations of engineers and architects the Crystal Palace played a strong role which in itself demonstrates the process of Evaluation and judgment being based on a range of criteria and involving at the very least Aesthetics, and Ethics. The whole enterprise contributed to knowledge refinement largely through an Empirical process.

\section{Conclusion}

The assertion in this paper is that it would be advantageous to introduce Philosophy into the undergraduate engineering curriculum. A study of the History of Science and Engineering can provide a bedrock of context for students. However a course in philosophy has the potential to allow engineering students and indeed graduate students too see the activities of their profession in a new light. Engineering involves the use of and contribution to knowledge over widespread domains. The logic that is used is highly disparate in nature, significant ethical considerations are inherent in most engineering endeavours, and aesthetic aspects can be fundamental to the outcome of the engineering process. Stephen Johnston, Alison Lee, and Helen McGregor, University of Technology, Sydney, Australia in a paper Engineering as Captive Discourse contribute a number of insights into engineering education ${ }^{12}$. One such point made expresses their "concern that the discourse of engineering education has been dominated by the discourse of engineering science, to the virtual exclusion of other discourses which contribute importantly to the practice of engineering". And this leads to or can lead to a de-contextualising of engineering and engineering educational programmes. Using the tools available from that activity called 'Philosophy', engineering educators could well be advised to closely examine how it constructs its engineering programmes and to balance the scientific with the nonscientific.

Finally, engineers should be accountable to society (in both a local and global sense). Part of that accountability is the responsibility to explain how engineering carries out its function in a manner intelligible to the non-engineer. Prof Louis Bucciarelli's book Engineering Philosophy examines "how the concerns of philosophers are relevant to engineering thought and practice - in negotiating tradeoffs, in diagnosing failure, in constructing adequate models and simulations, and in teaching" . That Philosophical considerations are timely within the Engineering profession would hardly be disputed and the Royal Academy of Engineering (RAE) in the UK has recently published an article in which it sets the scene for a project titled The Philosophy of Engineering ${ }^{14}$. The general aim of that project is to gain a greater understanding of the nature of the engineering profession and the discipline in general. Whilst not agreeing that there is a need to develop a Philosophy of Engineering, this author certainly agrees with the general aims of the RAE. Philosophy, its branches, its language and 'tools' has much to offer the engineer in understanding themselves and in turn to relate that understanding to the greater community. 
Acknowledgment. Some of the material used in this article is taken from two chapters written by the author in a book published in January 2007, Philosophy in Engineering, Editors Steen Christensen, Martin Meganck, Bernard Delahousse. Academica, Aarhus. The writing and publishing of the book was supported by a grant from the European Commission's Socrates/Erasmus programme.

\section{Bibliography}

1. Cardwell D, The Fontana History of Technology. Fontana Press (1994).

2. Mitcham C., The Importance of Philosophy to Engineering. Technos Vol. XVII/3 1998 / http://campusoei.org/salactsi/teorema02.htm

3. Bo Mou (Ed.) (2001), Two Roads to Wisdom?: Chinese and Analytic Philosophical Traditions. Open Court, Chapter 3: Philosophy as Engineering.

4. Petroski H. (1985), To Engineer is Human: The Role of Failure in Successful Design, St Martin's Press, New York.

5. Steen Christensen, Martin Meganck, Bernard Delahousse (eds). Academica, Aarhus (2007). Chapter 4

6. Anderson W. (1990), Reality Isn't What It Used To Be. HarperCollins [as given in http://www.greeleynet.com/ cnotess/glossn.htm]

7. http://onlineethics.org/index.html

8. http://www.co-design.co.uk/teachers/curriculum/aesthetics/aestheticshome.html

9. http://www-personal.engin.umich.edu/ yililiu/Yili-Liu-Engin-Aesthetics-5th-IE-2000.pdf

10. Steen Christensen, Martin Meganck, Bernard Delahousse (eds). Academica, Aarhus (2007). Chapter 7

11. Petroski H (1996). Invention by Design: How Engineers get from Thought to Thing. Harvard University Press

12. Johnston S. (1996), http://scholar.lib.vt.edu/ejournals/SPT/v1_n3n4/Johnston.html

13. Bucciarelli L. (2003), Engineering Philosophy. Delft University Press.

14. The Royal Academy of Engineering: Ingenia, March 2006, Issue 26 